\title{
Pættir sem hafa áhrif á stöðu kynjanna í íslensku atvinnulífi: Heildarmynd sýnd með áhrifariti
}

\author{
Snjólfur Ólafsson, Erla S. Kristjánsdóttir, Lára Jóhannsdóttir og Póra \\ H. Christiansen ${ }^{1}$
}

\begin{abstract}
Ágrip
Krafa um jafna stöðu kynjanna í íslensku atvinnulífi hefur verið áberandi undanfarin misseri, pví prátt fyrir að margt hafi áunnist er enn talsverður kynjamunur til staðar, t.d. hvað varðar laun og hlutfall kynja í stjórnunar- og stjórnendastöðum. Mikið hefur borið á kröfunni um að konur fái laun til jafns við karla og tilraunir gerðar til að fá konur til starfa í dæmigerðum karlastéttum og karla í dæmigerðum kvennastéttum. Staða kynjanna í atvinnulífinu er flókið fyrirbæri sem hefur verið rannsakað bæði á Íslandi og erlendis. Рað sem einkennir slíkar rannsóknir er að pær snúast í flestum tilvikum um afmarkaðan pátt viðfangsefnisins, t.d. launamun kynjanna, kvennastéttir, tilvist glerpaks eða mun á stjórnarháttum kynjanna. Tilgangurinn með pessari grein er að draga upp heildarmynd af pví flókna viðfangsefni sem staða kynjanna í íslensku atvinnulífi er, með pví að greina meginatriði málsins og áhrif peirra hvert á annað og sýna með einu áhrifariti. Niðurstöðurnar eru meðal annars afrakstur átta rýnifunda um viðfangsefnið í heild eða einstaka mikilvæga pætti pess. Meginframlag greinarinnar er sú heildarmynd sem fæst og sýnd er með áhrifariti. Prír pættir koma fram sem sérstaklega mikilvægir pættir heildarmyndarinnar, en pað eru ólík fjölskylduábyrgð, staðalmyndir kynjanna og frami kvenna í fyrirtækjum. Áhrifaritið gagnast sem grunnur að frekari rannsóknum, ásamt pví að hafa hagnýtt gildi fyrir pá sem vinna að pví að bæta stöðu kynjanna í íslensku atvinnulífi.
\end{abstract}

\begin{abstract}
Demands for closing the gender gap in the Icelandic labor market have become louder recently because in spite of great strides towards gender equality, the gender pay gap still exists and the genders are still not equally represented in top management positions and on corporate boards. Calls for equal pay and equal opportunities for women in traditionally masculine jobs and for men in traditionally feminine jobs have been the loudest. Gender (in)equality in the labor market is a complex issue that has been studied both in Iceland and abroad. Those studies have predominantly focused on specific aspects of the issue, such as the gender pay gap, the gendered labor market, the glass ceiling, or gender differences in management. This study aims to generate a comprehensive map that encompasses
\end{abstract}

1 Snjólfur Ólafsson er prófessor við Viðskiptafræðideild Háskóla Íslands. Netfang: snjolfur@hi.is. Erla S. Kristjánsdóttir er dósent við Viðskiptafræðideild Háskóla Íslands. Lára Jóhannsdóttir er prófessor við Umhverfis- og auðlindafræði, Háskóli Íslands. Póra H. Christiansen er aðjúnkt við Viðskiptafræðideild Háskóla Î́slands.

This work is licensed under a Creative Commons Attribution 4.0 License.

DOI: https://doi.org/10.24122/tve.a.2019.16.1.5

(C) Tímarit um viðskipti og efnahagsmál

www.efnahagsmal.is 
the complexity of the influence of gender in the labor market and to present an influence map depicting the most influential issues, their interrelationships and how they interact. The findings are based on eight focus-group meetings, some of which dealt with the whole issue and some of which focused on a subset of issues. The main contribution of the paper is the resulting comprehensive influence map. Three issues appear as especially influential in the map, i.e. different family responsibilities, gender stereotypes, and women's professional advancement in organizations. The influence map is a valuable foundation for further research and a practical contribution for those who aim to reduce the gender gap in the Icelandic labor market.

\section{JEL flokkun: M14; M51}

Lykilorð: Staða kynjanna; áhrifarit; fjölskylduábyrgð; staðalmyndir; frami kvenna.

Keywords: Gender equality; influence maps; family responsibility; stereotypes; women's advancement.

\section{Factors affecting gender (in)equality in the Icelandic labor market: A comprehensive influence map}

\section{Inngangur}

Baráttan fyrir jafnrétti kynjanna hefur staðið lengi yfir og pykir mörgum ganga hægt að jafna stöðu kynjanna, meðal annars í íslensku atvinnulífi, sem er útgangspunktur í pessari rannsókn. Kynjajafnrétti er mikilvægt, ekki bara út frá sjónarmiði um réttlæti, heldur einnig í efnahagslegu tilliti (Slotsky, 2006), sem og út frá velgengni fyrirtækja (ElborghWoytek o.fl., 2013). Staða kynjanna í íslensku atvinnulífi er ójöfn að mörgu leyti. Kynbundinn launamunur mælist til dæmis gjarnan á bilinu 5-10\% (Hagstofa Íslands, 2018; Einar Mar Pórðarson o.fl., 2008; Sigurður Snævarr, 2015), hlutfall kvenna í framkvæmdastjórnum er nálægt 15\% og engin kona stýrir skráðu fyrirtæki á markaði (Nasdaq Global Newswire, 2017). Rannsóknir á stöðu kynjanna í atvinnulífinu snúast að jafnaði um afmarkaða pætti málsins, t.d. um launamun kynjanna (Aðalsteinn Leifsson og Aldís G. Sigurðardóttir, 2010; Einar Mar Pórðarson, Heiður Hrund Jónsdóttir, Fanney Pórsdóttir, Ásdís A. Arnalds og Friðrik H. Jónsson, 2008; Gyða Margrét Pétursdóttir, 2010; Porlákur Karlsson, Margrét Jónsdóttir og Hólmfríður Vilhjálmsdóttir, 2007), kvennastéttir og kynbundið náms- og starfsval (Fjóla Pórdís Jónsdóttir og Ingi Rúnar Eðvarðsson, 2013; Guðbjörg Vilhjálmsdóttir, 2004; Sif Einarsdóttir, 2005; Puríður Sigurjónsdóttir og Sif Einarsdóttir, 2011), kynjakvóta og hindranir á framgangi kvenna (Axelsdóttir og Einarsdóttir, 2017; Guðbjörg Linda Rafnsdóttir og Margrét Porvaldsdóttir, 2012; Unnur Dóra Einarsdóttir, Erla S. Kristjánsdóttir og Póra H. Christiansen, 2017) eða mun á stjórnarháttum kynjanna og stöðu kynjanna í leiðtogahlutverki (Júlíusdóttir, Rafnsdóttir, Einarsdóttir, 2018; Margrét Sæmundsdóttir, 2009).

Tilgangurinn með pessari grein er að draga fram heildarmynd af stöðu kynjanna í íslensku atvinnulífi. Til pess er notað áhrifarit par sem sýnd eru atriði sem vega pungt og hvernig pau hafa áhrif hvert á annað. Á pennan hátt sýnir ein mynd, p.e. áhrifaritið, ekki eingöngu hver meginatriði viðfangsefnisins eru, heldur er einnig hægt að sjá á einfaldan hátt margt fleira, t.d. hvaða atriði hafa mikil áhrif á tiltekið atriði og ýmsar orsakakeðjur. Markmið rannsóknarinnar er pví ólíkt pví sem tíðkast og par með rannsóknaraðferðin. Hún felst í pví að draga saman sýn sérfræðinga og hagsmunaaðila á tiltekna pætti í íslensku samfélagi, orsakir, áhrif og hugsanlegar aðgerðir og kortleggja heildarmynd par sem hver hluti myndarinnar byggist á sýn margra einstaklinga. Hlutverk rannsakenda er að raða sýn peirra allra saman pannig að hún myndi eina heild. Sú heildarmynd sem fæst og sýnd er með áhrifariti er par af leiðandi meginframlag greinarinnar. Leitast er við að 
svara eftirfarandi rannsóknarspurningu; Hvaða pættir geta stuðlað að jafnri stöðu kynjanna i íslensku atvinnulifi? Rannsóknin einskorðast við að skoða hvaða pættir geta hugsanlega jafnað stöðu karla og kvenna en ekki annarra hópa í atvinnulífinu, svo sem annarra kynja, innflytjenda eða fatlaðra. Slíkt er mikilvægt, en efni í aðra rannsókn. Rannsóknarspurningin byrjar á: Hvaða pættir geta stuðlað að og felur pannig í sér að fjallað er um áhrifapætti og að horft er til framtíðar.

Í rannsókninni er dregið fram í hverju ójöfn staða kynjanna í atvinnulífinu felst og hvað geti orðið til pess að jafna pá stöðu. Pess vegna eru líka dregin fram atriði sem ekki eru beint hluti af atvinnulífinu en hafa áhrif á stöðu kynjanna í atvinnulífinu, en par má nefna námsval og fjölskylduábyrgð fólks á vinnumarkaði sem dæmi. Valin var sú leið að halda rýnifundi með sérfræðingum og hagsmunaaðilum sem hafa mismunandi sýn á viðfangsefnið. Eftir hvern rýnifund var unnið áhrifarit, en sameiginlega nýtast áhrifaritin til að fá heildarsýn á viðfangsefnið. Alls voru haldnir 8 rýnifundir með samtals 43 einstaklingum, sjá nánar í kafla um rannsóknaraðferð. Fundirnir fóru fram í janúar til mars 2017.

Í næsta kafla er fræðileg umfjöllun um ólíka stöðu kynjanna í atvinnulífinu. Par á eftir er ítarleg lýsing á rannsóknaraðferðinni og gerð grein fyrir helstu niðurstöðum rannsóknarinnar. Að lokum eru umræður og lokaorð.

\section{2 Ójöfn staða kynjanna í íslensku atvinnulífi}

Ójöfn staða kynjanna í íslensku atvinnulífi er tilefni rannsóknarinnar. Samkvæmt Katrínu Ólafsdóttur hefur staða kvenna á íslenskum vinnumarkaði batnað undanfarinn áratug og lýsir pað sér t.a.m. í minnkandi launamuni og fjölgun kvenna í áhrifastöðum. Hindranir eru pó enn til staðar og hafa t.d. staðalmyndir hamlandi áhrif á jafna atvinnupátttöku (Ólafsdóttir, 2018). Skýrslur Velferðarráðuneytisins, Staða kvenna og karla á íslenskum vinnumarkaði (Katrín Ólafsdóttir og Steinunn Rögnvaldsdóttir, 2015) og Skýrsla félags- og jafnréttismálaráđherra um stöđu og próun jafnréttismála 2015-2017 (Velferðarráðuneytið, 2018) gera ítarlega grein fyrir stöðu og próun síðustu ára, t.d. í pví hversu kynjaskiptur vinnumarkaðurinn er, bæði lóðrétt og lárétt, hversu mikill skýrður og óskýrður launamunur er milli kynjanna, hversu kynjað náms- og starfsval er, hversu mikill munur er á töku fæðingarorlofs, hversu kynjuð verkaskiptingin inni á heimilum er og hvert hlutfall kvenna er í stjórnum og framkvæmdastjórnum fyrirtækja. Skýrsla félags- og jafnréttismálaráðherra um stöðu og próun jafnréttismála 2015-2017 bendir jafnframt á að „,jafnrétti kynjanna kemur ekki af sjálfu sér. Рað krefst sameiginlegra aðgerða og samstöðu margra um baráttu kvenna fyrir mannréttindum, pólitísks vilja og verkfæra í formi löggjafar, kynjaðrar fjárlagagerðar og kynjakvóta“" (2018, bls. 9). Ekki er nóg að fyrirtæki setji sér jafnréttisáætlun, pau purfa að taka frumkvæði að virkum aðgerðum til að jafna stöðu kynjanna (Arney Einarsdóttir, Katrín Ólafsdóttir og Laura Nesaule, 2018).

prátt fyrir pann kynjamun sem fram kemur í skýrslu Velferðarráðuneytisins (Katrín Ólafsdóttir og Steinunn Rögnvaldsdóttir, 2015) er Ísland í efsta sæti, með minnstan kynjamun (e. gender gap) samkvæmt skýrslu World Economic Forum (2018) eins og undanfarin ár. Munur á stöðu kynjanna í íslensku pjóðfélagi mælist pannig minnstur í heimi, en pví er haldið fram að $85 \%$ af kynjabilinu hafi verið lokað á Íslandi. Vísitalan sem setur Ísland í efsta sæti er vegið meðaltal af fjórum páttum og einn peirra er tækifæri og pátttaka í atvinnulífinu (e. economic participation and opportunity) og par er Ísland í fjórtánda sæti. Hinir prír pættirnir snúast um menntunarstig (e. educational attainment), heilbrigði (e. health and survival) og stjórnmál (e. political empowerment) (World Economic Forum, 2018).

Atvinnupátttaka á Íslandi er hæst af öllum OECD ríkjunum og kynjamunur á atvinnupátttöku minnstur (OECD, e.d.). Atvinnupátttaka kvenna árið 2018 var tæplega 78\% (Hagstofa Íslands, 2019a), en engu að síður er vinnumarkaðurinn talsvert kynjaskiptur (Velferðarráðuneytið, 2018). Nefna má að árið 2014 voru einungis 11\% iðnaðarmanna konur, $17 \%$ skrifstofufólks karlar og í byggingarstarfsemi og mannvirkjagerð voru einungis 5\% konur (Sigurður Snævarr, 2015). Í sumum fyrirtækjum er yfirgnæfandi meirihluti af sama 
kyni, s.s. í ýmsum tæknifyrirtækjum. Pá var kynjaskipting mikil í sumum starfstéttum fyrir nokkrum áratugum, en er pað ekki lengur. Par má nefna að hlutfall kvenna í læknastétt er um priðjungur og fer ört hækkandi, enda eru nú talsvert fleiri konur en karlar í hópi lækna undir fertugu, en í aldurshópnum 60 ára og eldri er hlutfall karla nær 90\% (Læknafélag Íslands, e.d.).

Hlutföllin í menntakerfinu hafa jafnast mikið eða jafnvel snúist við í mörgum námsgreinum. Konur eru nú tvöfalt fleiri en karlar í hópi peirra sem útskrifast úr háskólum á Islandi (Hagstofa Íslands, e.d.). Alls eru pær 69\% útskrifaðra meistaranema frá Háskóla Íslands og 66\% peirra sem útskrifast úr grunnnámi (Háskóli Íslands, 2018). Peim fjölgar einnig í verkfræðitengdu námi, en eru pó enn langt undir 40\% brautskráðra með háskólapróf í verkfræði (Hagstofa Íslands, e.d.).

Kjararannsóknir sýna ótvírætt að konur hafa umtalsvert lægri laun en karlar (Hagstofa Íslands, 2018; VR, e.d.b). Margar leiðir eru til að reikna launamun og engin ein sú rétta (Sigurður Snævarr, 2015, Einar Mar Pórðarson o.fl., 2008). Í sumum tilvikum er eingöngu launafólk í 100\% vinnu tekið með í samanburðinum, en stundum líka fólk í hlutastarfi. Stundum eru föst mánaðarlaun lögð til grundvallar og stundum heildarlaun. Stundum er byggt á meðaltölum og stundum á miðtölum. Í rannsóknum er launamuni gjarnan skipt í tvennt. Annars vegar er sá hluti launamunarins sem má skýra með páttum sem rannsakendur telja til eðlilegra skýringa, svo sem hvað varðar vinnutíma. Pegar sá munur hefur verið dreginn frá stendur eftir pað sem ýmist er kallað óútskýrður launamunur eða kynbundinn launamunur (Einar Mar Pórðarson o.fl., 2008). Pessi munur er umdeildur, meðal annars hvernig beri að túlka hann, en ekki er tekin afstaða til pess hér.

Hlutfall kvenna í áhrifastöðum í pjóðfélaginu er enn lágt (Hagstofa Íslands, 2019b; Katrín Ólafsdóttir og Steinunn Rögnvaldsdóttir, 2015; Velferðarráðuneytið, 2018) og hlutur kynjanna í fjölmiðlum er einnig ójafn (Valgerður Jóhannsdóttir og Porgerður Einarsdóttir, 2015). Af stærstu fyrirtækjum landsins, með 250 starfsmenn eða fleiri, eru konur við stjórn í einungis 12,8\% fyrirtækja (Hagstofa Íslands, 2019b) og karlar stýra nú öllum peim fyrirtækjum sem skráð eru í Nasdaq kauphöllina á Íslandi.

Í bréfi frá Kauphöllinni dagsettu 3. mars 2017 par sem boðið var til athafnar 8. mars 2017 segir m.a.: „43 kauphallir um allan heim, p.á.m. Nasdaq Iceland, munu hringja bjöllunni fyrir jafnrétti kynjanna, til að vekja athygli á pví að jafnrétti er nauðsynlegt til að drífa áfram alpjóðlegt efnahagslíf og að einkageirinn hefur mikilvægu hlutverki að gegna í pessari próun”. Par segir jafnframt: „Hlutdeild kvenna í stjórnum meðalstórra og stórra fyrirtækja er innan við fjórðungur. Pá eru konur innan við 10\% framkvæmdastjóra á meðal stærstu fyrirtækja og fjárfesta og engin kona stýrir skráðu fyrirtæki á markaði" (Nasdaq Global Newswire, 2017).

Pó settar hafi verið fram eðliskenningar eins og t.d. Hakim (2002) sem útskýrir stöðu kvenna á vinnumarkaði út frá valkenningu (e. preference theory) eða að konur séu líklegri til að vera í lægri stöðu, í hlutastarfi eða að leggja áherslu á sveigjanleika í starfi vegna pess að pær velji frekar að forgangsraða fjölskyldunni fram yfir starf á vinnumarkaði, pá hafa pær hlotið takmarkaðan stuðning. Til dæmis má nefna niðurstöður McRae (2003) sem bendir á að ytri aðstæður og takmarkaðir möguleikar kvenna til atvinnupátttöku eins og t.d. skortur á barnagæslu stýri hegðun peirra frekar en að pær velji að forgangsraða fjölskyldu framyfir starf á vinnumarkaði. Hakim (2006) bendir hins vegar á að vegna pess að konur forgangsraði frekar í págu fjölskyldunnar séu áhrif vinnumarkaðsúrræða eins og sveigjanlegs vinnutíma frekar til pess fallin að auka kynjamuninn en minnka hann.

Félagsmótunarkenningar skýra ólíkan framgang karla og kvenna út frá pví að samfélagsleg viðhorf til karla og kvenna séu ólík, enn sé konum ætlað að axla meginábyrgð á umönnun barna og heimilis en körlum að vera fyrirvinnur (Blair-Loy, 2001). Ólíkar staðalmyndir kynjanna verða til pess að konum og körlum eru ætluð ólík kynhlutverk og kynhlutverk kvenna fellur ekki að leiðtogahlutverkinu (Eagly og Karau, 2002). Samfélagið 
samsamar pannig konur síður en karla við hlutverk stjórnandans sem flestir gæða karllægum eiginleikum (Koenig, Eagly, Mitchell og Ristikari, 2011; Schein, 1973, 2007), leiðtogahegðun kvenna er metin neikvæðar en samskonar leiðtogahegðun karla (Eagly og Karau, 2002) og framlag kvenna er fremur vanmetið til launa en framlag karla (Blau og Kahn, 2007). Kynjaðar staðalmyndir pýða að einstaklingum eru eignaðir eiginleikar vegna kyns, t.d. er gert ráð fyrir að kona sé samvinnupýðari og geri minni kröfur í samningum en karl. Petta getur haft pau áhrif að konu eru boðin lægri laun og ef hún gerir gagntilboð eða sýnir hörku í samningum pá samræmist pað ekki staðalmyndinni og hegðun sem metin væri jákvæð hjá karli er metin sem neikvæð hjá konu vegna ósamræmis við staðalmyndina (Eagly og Karau, 2002; Kray og Thompson, 2004). Pó samantekt Koenig o.fl. (2011) á rannsóknum bendi til pess að eitthvað sé að draga úr pví hversu karllæg staðalmynd leiðtogans er, pá sýna pær einnig fram á að karlar eru líklegri en konur til að álíta leiðtogahlutverkið karllægt. Benda pær á að par sem karlar eru í miklum meirihluta í æðstu stjórnendastöðum pá skapi staðalmyndir kynjanna og karllæg staðalmynd leiðtogans hindrun og dragi úr möguleikum kvenna á leiðtogastöðum. Mikilvægt er pví að horfa til staðalmynda kynjanna og einnig áhrifa pess hvernig staðalmyndir hlutverka og starfa samræmast kynhlutverkum.

Íslenskar konur í millistjórnendastöðum upplifa hindranir vegna staðalmynda sterkt (Unnur Dóra Einarsdóttir, Erla S. Kristjánsdóttir og Póra H. Christiansen, 2017) og bæði konur og karlar í yfirstjórnum fyrirtækja telja íhaldssamar staðalmyndir hindra framgang kvenna í stjórnunarstöður á íslenskum vinnumarkaði (Guðbjörg Linda Rafnsdóttir og Margrét Porvaldsdóttir, 2012). Samkvæmt niðurstöðum Guðbjargar Lindu Rafnsdóttur og Margrétar Porvaldsdóttur (2012) hafna yfirstjórnendur pví að ólíkt eðli karla og kvenna geri konur síðri kost í hlutverki yfirstjórnenda fyrirtækja. Íslenskir og norskir yfirstjórnendur eru auk pess líklegri til að styðja að fyrirtæki geri meira til að fá konur til starfa í topp stöður og jafna fjölskylduábyrgðina, en mun ólíklegri til að styðja aðgerðir eins og jákvæða mismunun eða kynjakvóta (Axelsdóttir og Halrynjo, 2018). Rannsóknir sýna að karlar og konur í leiðtogastöðum í íslensku atvinnulífi upplifa ólíkar áskoranir og hvílir ábyrgð fjölskyldu og heimilis pyngra á konunum en körlunum (Júlíusdóttir, Rafnsdóttir og Einarsdóttir, 2018). Samkvæmt niðurstöðunum eru karlar í leiðtogastöðum einnig líklegri til að eiga maka sem vinnur styttri vinnudag og helgar sig meira heimilinu og pannig viðheldur fjölskyldumynstrið aðstöðumuni kynjanna í atvinnulífinu.

\section{Rannsóknaraðferð}

Rannsókn pessi snýst um að ná utan um flókið viðfangsefni par sem orsakasamhengi er mikilvægur páttur. Hefðbundnar eigindlegar eða megindlegar rannsóknaraðferðir henta ekki vel pegar skoða parf flókin viðfangsefni eins og tengsl og áhrifapætti til að jafna stöðu kynjanna eins og gert er í pessari rannsókn. Í rannsókninni er unnið með rit af peim toga sem fjallað er um hér að neðan og rannsakendur kalla áhrifarit.

Sú rannsóknaraðferð sem notuð er í rannsókninni er sérsniðin að pessari rannsókn, en byggir einkum á tveimur aðferðum, IM og SODA. Í báðum pessum aðferðum eru áhrif pátta á aðra pætti sýnd með örvum á ritum sem kölluð eru áhrifarit, en eru kölluð „,influence map" í fyrri aðferðinni en „cognitive map" í peirri seinni. Pessum tveimur aðferðum verður nú gerð skil í nokkrum málsgreinum en síðan gerð grein fyrir rannsóknaraðferðinni sem notuð var í rannsókninni.

IM (e. interactive management) er aðferð sem var próuð til að gera hópum kleift að vinna við flókin viðfangsefni og vandasamar aðstæður og sameina framlag einstaklinga með mismunandi bakrunn, reynslu og viðhorf (Alexander, 2002; Broome, DeTurk, Kristjánsdóttir, Kanata og Ganesan, 2002). Pessa aðferð má nota til að draga saman sýn einstaklinga á tiltekinn pátt í íslensku samfélagi, p.e. stöðu kynjanna í atvinnulífinu. Hver einstaklingur pekkir vel til einhvers hluta viðfangsefnisins en pað er hlutverk rannsakanda 
að vinna úr peim upplýsingum sem frá einstaklingunum koma og setja fram á myndrænan hátt heildarmynd af viðfangsefninu. IM felst í pví að pátttakendur koma með hugmyndir og fundarstjórar (e. facilitators) sjá um að ferlið gangi vel fyrir sig án pess að hafa áhrif á umræðurnar. Fundarstjóri hvetur og eflir pátttakendur til umræðna með pví að sýna peim virðingu og umgangast pá sem sérfræðinga (Broome o.fl., 2002). Fundarstjórar vinna svo áhrifarit sem sýnir heildarmynd af viðfangsefninu.

Áhrifaritið veitir pátttakendum ekki aðeins yfirsýn yfir viðfangsefnið heldur sýnir einnig tengslin á milli fjölda pátta á kerfisbundinn hátt og sem hægt er að vinna með áfram. Áhrifaritið gerir rannsakendum kleift að skilja betur hvaða pættir hafa áhrif hver á annan, hvaða pættir standa í veginum fyrir jafnri stöðu kynjanna og hvað parf mögulega að gerast til að jöfnuði sé náð. IM aðferðin og áhrifaritin veita margvíslegar upplýsingar sem ekki væri hægt að ná fram með hefðbundnum rannsóknaraðferðum eins og spurningarlistum (Broome o.fl., 2002). IM aðferðin hefur verið notuð víða um heim til að vinna með margvísleg vandamál í skipulagsheildum; til dæmis til að endurhanna skipulagsheildir, próa framleiðsluvörur og við friðarumræður (Broome o.fl., 2002).

SODA (strategic options development and analysis) er aðferð sem próuð var af Colin Eden og fleirum (Eden, 1989; Rosenhead, 1989). Áhersla er lögð á að kortleggja áhrifapætti tiltekins viðfangsefnis og samhengi peirra, einkum í peim tilgangi að nýta pá greiningu sem undirstöðu fyrir stefnumótun. Liður í aðferðinni er að próa áhrifarit sem lýsa pví á ítarlegan hátt hvernig frekar fáir einstaklingar sjá tiltekið viðfangsefni, jafnvel með fleirum en 50 atriðum og ótal örvum sem sýna tengsl milli atriðanna. Pessi nálgun á margt sameiginlegt með notkun stefnukorta (e. strategy map) í stefnumiðuðu árangursmati (e. balanced scorecard) par sem stefnukortin eiga að endurspegla stefnu fyrirtækja (Kaplan og Norton, 2001; Snjólfur Ólafsson, 2005). Á slíkum stefnukortum eru almennt sett fram 15-25 atriði.

Hugsunin í SODA og skyldum aðferðum er að greining eða rannsókn á viðfangsefni snúist um að gera líkan af flóknu (e. complex and messy) viðfangsefni par sem meginatriði máls eru sýnd og orsakasamhengi eða áhrif á milli peirra (Herrera, McCardle-Keurentjes og Videira, 2016). Slík viðfangsefni tengjast gjarnan stefumótun (e. strategy, policy) og geta verið hjá fyrirtækjum, sveitarfélögum, öðrum skipulagsheildum eða viðfangsefnum sem snerta marga hagsmunaaðila (Farsari, Butler og Szivas, 2011). Í öllum tilvikum er unnið að pví að draga fram sameignlega sýn margra aðila og í öllum tilvikum er einn eða fleiri fundarstjóri (e. facilitator) sem vinnur að pví að próa líkan af viðfangsefninu í formi áhrifarits. Rýnifundir eru jafnframt páttur í vinnunni enda pótt stundum séu öðrum aðferðum blandað saman, t.d. einstaklingsviðtöl eða kannanir.

Markmiðið í pessari rannsókn var að gera áhrifarit sem lýsir pví hvaða pættir hafa áhrif á stöðu kynjanna í íslensku atvinnulífi. Ákveðið var að styðjast alfarið við rýnifundi par sem rýnifundir henta vel par sem áhrifaritið endurspeglar viðhorf margra einstaklinga sem pekkja vel til einhverra pátta viðfangsefnisis. Fræðilega pekkingin kemur á tvo vegu inn í áhrifaritið, annars vegar í gegnum pekkingu rannsakenda og hins vegar í gegnum ýmsa af pátttakendunum í rýnihópunum. Рað er svo í höndum rannsakenda að vinna áhrifaritið sem er meginniðurstaða rannsóknarinnar. Um pað er fjallað í kafla 3.2.

Á fyrstu fimm rýnifundunum var umræðuefnið hin almenna rannsóknarspurning; Hvaða pxttir geta stuðlað að jafnri stöðu kynjanna í íslensku atvinnulífi? Pessari rannsóknarspurningu var varpað fram fyrir pátttakendur að fást við á rýnifundunum. Ferlið á fundunum var prípætt: hugarflæði par sem pátttakendur skrifuðu niður eins margar hugmyndir og peim datt í hug, hugmyndaflokkun fundarstjóra (byrjunar pemagreining á töflu) og umræður um áhrifapætti til að svara rannsóknarspurningunni. Á síðustu premur rýnifundunum var unnið með niðurstöður fyrstu fimm fundanna og kafað dýpra í tiltekin pemu; p.e. jafnari hlutföll kynjanna í framkvæmdastjórnum, kynbundið náms- og starfsval og jafnari fjölskylduábyrgð kynjanna. Pessi pemu höfðu kristallast á fyrstu fundunum sem mjög mikilvæg pemu sem pörf væri að skoða og greina nánar. 


\subsection{Rýnifundir}

Rannsókn sem byggist á rýnihópum (e. focus group research) felur í sér að hópur einstaklinga er saman á fundi og ræðir tiltekið málefni par sem rannsakandi leiðir umræðuna. Yfirleitt eru haldnir nokkrir fundir, gjarnan með 6-10 einstaklingum á hverjum fundi (Kvale og Brinkmann, 2009). Раð fer eftir viðfangsefni og einstaklingunum á tilteknum fundi hvernig umræða próast en leitast er eftir umræðum meðal jafningja (Creswell, 2007). Almennt má segja að kosturinn við að hafa marga á fundi sé að pá koma að jafnaði fram fleiri ólík atriði en ef fáir taka pátt í fundinum. Kosturinn við að hafa færri pátttakendur er sá að pá fæst dýpri umræða um einstök umræðuatriði. Í pessari rannsókn voru haldnir 5 almennir rýnifundir og síðan 3 fundir um afmörkuð pemu. Í öllum tilvikum voru pátttakendur 5-7.

Pessi rannsóknaraðferð hentar vel pegar verið er að kanna ný svið (Kvale og Brinkmann, 2009). Rannsakendur vildu nálgast viðfangsefnið eins og um nýtt svið væri að ræða, meðal annars til pess að viðfangsefnið yrði skilgreint af hópi einstaklinga með mismunandi sýn á málið, frekar en eingöngu af rannsakendum sjálfum. Við val á einstaklingum á rýnifundina var miðað við að fá einstaklinga sem höfðu mikið til málanna að leggja varðandi einhvern pátt málefnisins sem til umræðu var. Einnig var horft til samsetningar hópsins og var farin sú leið að velja hópa einstaklinga á hvern fund sem voru ekki of ólíkir hvað pekkingu og reynslu varðar, m.a. til að fá fram jafningjaumræðu (Creswell, 2007), sjónarmiðin væru nógu ólík prátt fyrir pað. Eitt af pví sem rannsakendur vildu láta reyna á með pessum hætti var hvort einhver umdeild atriði myndu koma í ljós, annars vegar í umræðu í einstökum hópum eða pegar niðurstöður fundanna væru bornar saman. Pátttaka einstaklinga á rýnifundum fól í sér sampykki peirra (Burnett, 2009), en einnig fór forstig greiningar fram á fundum í samvinnu við pátttakendur.

Fyrirkomulag og framkvæmd fundanna var mjög í takt við aðferðir svokallaðrar Nominal Group Technique (Delbeq, Van De Ven og Gustafson, 1975); en eftir kynningu á rannsókninni og rannsóknaraðferð, rannsakendum og pátttakendum fengu pátttakendur tíma til að skrifa á miða atriði sem tengdust rannsóknarspurningunni. Hver einstaklingur skrifaði atriði sem voru mikilvæg í hans huga varðandi viðfangsefni fundarins. Síðan var farið hring eftir hring og einn miði fenginn frá hverjum pátttakanda, miðinn settur á töflu og stutt útskýring eða umræða fylgdi í kjölfarið eftir atvikum. Síðasta skrefið á rýnifundum rannsóknarinnar var að ræða sérstaklega um áhrifatengsl milli atriða sem búið var að flokka gróflega eftir pemum, t.d. hvaða atriði pað væru sem gætu stuðlað að breyttum staðalmyndum.

Á fyrsta fundinum voru pátttakendur ýmsir fræðimenn við Háskóla Íslands sem tengjast viðfangsefninu. Næstu tveir fundir voru með konum úr atvinnulífinu og var meðal annars haft samband við FKA (Félag kvenna í atvinnulífinu) og Ungar athafnakonur til að finna einstaklinga sem hefðu áhuga á málefninu. Fjórði fundurinn var með fulltrúum samtaka vinnuveitenda, p.e. Samtaka atvinnulífsins, Samtaka iðnaðarins, Viðskiptaráðs og Félags atvinnurekenda, og sá fimmti með fulltrúum stéttarfélaga, p.e. ASÍ, BSRB og BHM. Fjöldi pátttakenda á pessum fundum var (fjöldi kvenna + fjöldi karla) 5+1, 5+0, 5+0, $4+3$ og 3+2, eða alls 28 einstaklingar. Fram kemur kynjahalli pegar kemur að pátttakendum á fundunum, p.e. 22 konur og 6 karlar, en benda má á að pátttakendur voru útnefndir af hálfu peirra samtaka og stofnana sem leitað var til, vegna pekkingar peirra, reynslu og/ eða áhuga á málefninu.

Eftir rýnifundina fimm greindu rannsakendur prjá mjög mikilvæga pætti sem ástæða pótti til að ná betur utan um og voru haldnir prír rýnifundir til viðbótar, hver með sitt viðfangsefni. Pátttakendur á fyrsta rýnifundinum tókust á við spurninguna: Hvernig er hægt að jafna hlutfall kynjanna í framkvæmdastjórnum? Pátttakendur voru 3+4 einstaklingar, par af 5 með reynslu sem forstjórar stórra fyrirtækja. Annar fundurinn fjallaði um spurninguna: Hvernig má minnka kynbundið náms- og starfsval? Pátttakendur á peim fundi voru sérfræðingar í starfs- og námsráðgjöf, 6+0 talsins. Pema priðja fundarins var: Hvernig er hægt að 
jafna fjölskylduábyrgð kynjanna? Á peim fundi voru 6+1 áhugasamir einstaklingar, sumir með reynslu af rannsóknum á pessu sviði, einn varapingmaður og prír sem höfðu tekið pátt í rýnifundum í fyrstu umferð.

Fundirnir voru nokkuð ólíkir innbyrðis, einkum vegna pess að pátttakendur voru ólíkir og komu fram með ólík atriði. Fundarstjóri hefur einnig nokkur áhrif á gang fundar, m.a. til að tryggja að allir fái tækifæri til að tjá sig, en almennt var reynt að stýra umræðunni eins lítið og mögulegt var og leyfa pátttakendum að láta hana próast í pá átt sem peir vilja. Eftir atvikum bað stjórnandi hópinn um að ræða tiltekið atriði nánar, t.d. ef pað virtist vera mikilvægt en erfitt að ná utan um pað. Yfirleitt voru prír af rannsakendunum fjórum á fundunum, einn stýrði, annar var tilbúinn til aðstoðar eftir pörfum, m.a. við að flokka og raða miðum á töfluna og priðji fylgdist með.

\section{2 Úrvinnsla eftir rýnifundi}

Úrvinnsla gagna byggist á miðunum sem að pátttakendur skrifuðu á, pví sem rannsakendur heyrðu á fundunum og glósað var niður og pekkingu rannsakenda á viðfangsefninu. Ekki pótti ástæða til að hljóðrita fundina par sem markmiðið var að draga fram meginatriði málsins (draga upp heildarmynd) en ekki greina viðfangsefnið á dýptina í upphafi. Рað var pó gert í síðustu premur rýnifundum par sem kafað var dýpra í tiltekin viðfangsefni. Teknar voru ljósmyndir af töflunni með miðunum pegar peir höfðu verið grófflokkaðir og áhrifatengsl teiknuð upp á fundunum í peim tilgangi að auðvelda frekari greiningu gagna.

Eftir hvern fund var texti hvers miða fyrir sig skrifaður orðréttur í skjal. Næsta skref var að flokka efnið og pemagreina, með eitt atriði sem lýsandi pemaheiti. Dæmi um skref tvö í úrvinnsluferli er að atriðið Kynjafræði á öllum skólastigum var valið sem heiti á pema sem inniheldur atriði eins og t.d. Kynjafræði i skólum og Byrja í leikskóla að fræða.

Til að sannprófa að svipaðar áherslur kæmu út við pessa pemagreiningu pá tóku prír rannsakendur að sér að pemagreina hver í sínu lagi niðurstöður fyrsta fundarins og var niðurstaðan að áherslur við flokkun efnisatriða var svipuð, pó svo að peir notuðu mismunandi skýringarheiti á pemun. Rannsakendur sammæltust síðar um pau heiti sem notuð eru og eru pau kölluð efnisatriði hér. Priðja skrefið var að taka efnisatriðin og setja upp í áhrifarit par sem sýnt er hvernig eitt efnisatriði getur haft áhrif á annað. Lokaskrefið var að umorða efnisatriði eftir pörfum pannig að áhrifaritin séu auðlesanleg. Dæmi um umorðun í áhrifariti er að efnisatriðinu Vantar fyrirmyndir i æðstu stöðum var breytt í Fleiri kvenfyrirmyndir i æðstu stöðum og Staðalmyndir um kyn, karlmennsku/kvenleika var breytt í Staðalmyndir fjari út. Pá voru settar inn örvar frá einu efnisatriði að öðru, sem merkir að hið fyrra stuðlar að hinu síðara.

Gert var eitt áhrifarit eftir hvern fund og síðan var efni peirra allra dregið saman í eitt heildaráhrifarit sem kynnt er í pessari grein. Ýmis atriði komu fram á mörgum áhrifaritum, jafnvel öllum, en sum komu aðeins fram á tveimur áhrifaritum. Næsti kafli fjallar um pá heildarmynd sem varð til eftir greiningu heildargagna.

\section{Niðurstöður}

Meginniðurstaða rannsóknarinnar er áhrifaritið á mynd 1, en pað er unnið úr peim áhrifaritum sem urðu til eftir hvern rýnifund. Pannig endurspeglar mynd 1 pau viðhorf sem komu fram á rýnifundunum. Í kafla 4.1. er áhrifaritið sett fram og útskýrt hvað örvarnar merkja. Par á eftir er í köflum 4.2, 4.3 og 4.4 dregin fram margt sem áhrifaritið felur í sér og pað útskýrt nánar.

\section{1 Áhrifarit sem sýnir heildarmynd viðfangsefnis rannsóknar}

Áhrifaritið á mynd 1 sýnir efnisatriði sem dregin voru fram við úrvinnslu gagna frá rýnihópafundunum. Hvert efnisatriði er fulltrúi fyrir safn atriða sem fela í sér svipaða hugsun. 
Efnisatriðin eru orðuð pannig að áhrifin sem dregin eru fram á milli peirra eru í öllum tilvikum jákvæð, p. e. fela í sér að stuðlað er að jákvæðum breytingum.

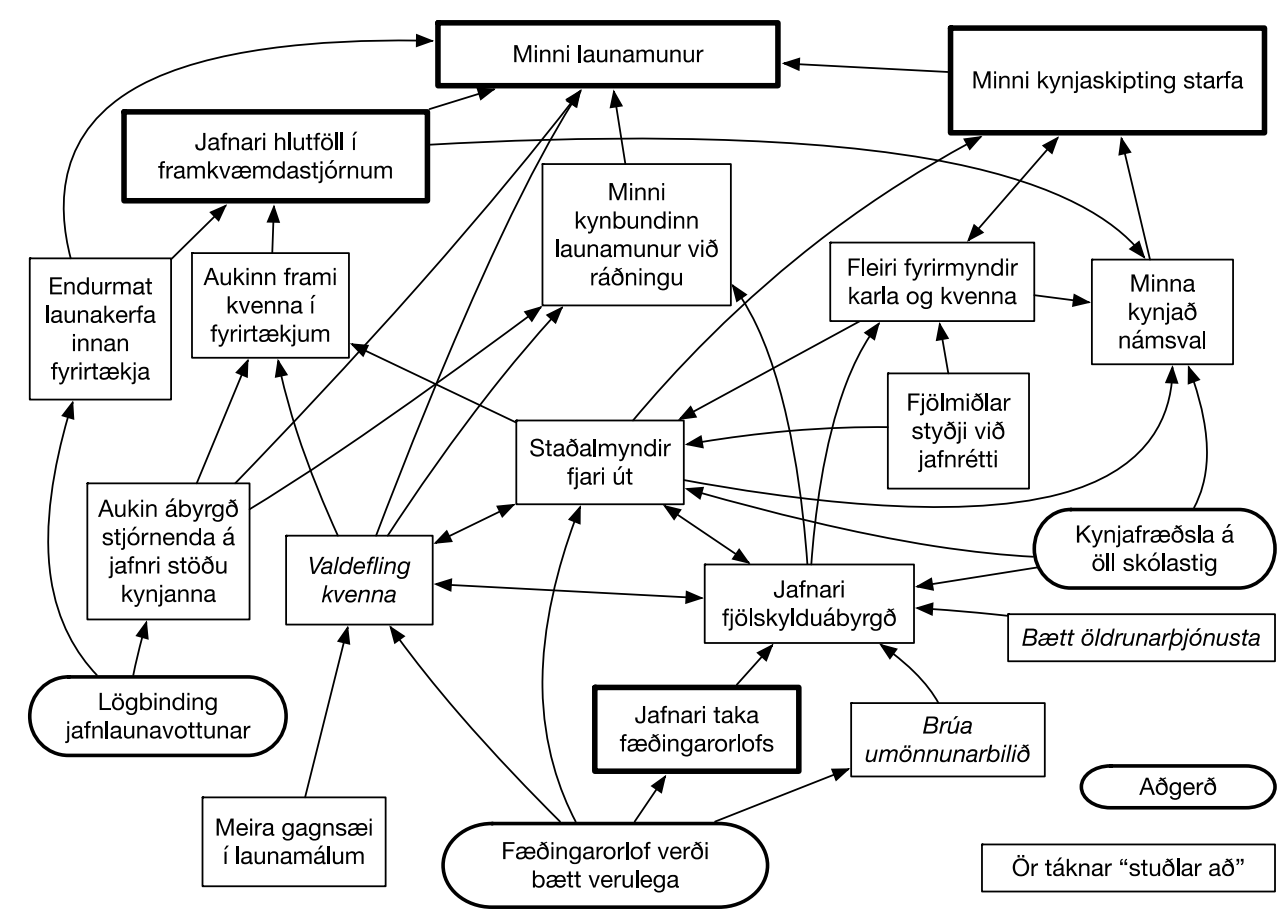

Mynd 1. Áhrifarit sem sýnir heildarmynd viðfangsefnisins: Hvaða pættir geta stuðlað að jafnri stöðu kynjanna í íslensku atvinnulífi?

Í flestum tilvikum voru áhrifin sem örvarnar lýsa nefnd á rýnifundum, oft af mörgum pátttakendum. Ekki er reynt að sýna öll áhrif með örvum heldur er dregið fram pað sem telja má mikilvæg tengsl. Ein leið til að lesa ritið er að horfa á tiltekið efnisatriði og skoða annars vegar hvaða atriði hafa áhrif á pað (örvar inn í atriðið) og hins vegar á hvaða atriði petta tiltekna efnisatriði hefur áhrif á/stuðlar að (örvar út úr atriðinu).

\section{1 Útskýringar á áhrifariti}

Á áhrifaritinu eru 20 efnisatriði. Á rýnifundunum voru ýmis atriði nefnd sem ekki koma fram á ritinu og var pað hlutverk rannsakenda að sameina efnisatriði eða sleppa peim. Við slíka greiningu var horft til pess hvort atriðin hefðu verið rædd á einum eða fleiri fundum og hvernig umræðan var um pau. Efnisatriði sem fólu í sér svipaða merkingu voru sameinuð og sameiginlegt heiti fundið á viðkomandi efnisatriði (pema) eins og áður hefur verið útskýrt.

Efnisatriðin á áhrifaritinu eru í mismunandi römmum sem eru notaðir til flokkunar. Hér er valin sú leið að vera með prjár gerðir ramma:

1. Efnisatriði í ferhyrningum má hugsa sem breytingar sem purfa að eiga sér stað ef staða kynjanna á að jafnast. Nefna má sem dæmi Jafnari fjölskylduábyrgð, Endurmat á launakerfum fyrirtækja, Minna kynjað námsval og Valdeflingu kvenna.

2. Ferhyrningar sem eru dregnir með pykkari línum en aðrir fela í sér efnisatriði sem pátttakendur töldu að væri fremur auðvelt að próa mælikvarða fyrir, sem geti sýnt hvernig staðan próast á næstu árum. Petta eru atriðin Jafnari hlutföll i framkvæmdastjórnum, Minni kynjaskipting starfa, Jafnari taka fæðingarorlofs og Minni launamunur. 
3. Á fundunum var sérstaklega reynt að fá pátttakendur til að tjá sig um mögulegar aðgerðir. Efnisatriði sem fela í sér mögulegar aðgerðir eru sett í sporöskjulaga ramma. Hér er um að ræða Lögbindingu jafnlaunavottunar, Fæðingarorlof verði bætt verulega og Kynjafræðslu á öllum skólastigum. Önnur atriði á áhrifaritinu fela ekki í sér aðgerðir, nema hugsanlega að litlu leyti, heldur eru fyrst og fremst afleiðingar af fjölmörgum aðgerðum og ákvörðunum margra aðila.

Prjú efnisatriði fela í sér aðgerðir (sporöskjulaga rammar), eins og nefnt var hér að framan. Рað er ljóst hvað Lögbinding jafnlaunavottunar stendur fyrir, enda var komið fram frumvarp, sem styður við pessa aðgerð, pegar fundirnir áttu sér stað (lög nr. 10/2008 um jafnlaunavottun). Fæðingarorlof verði bætt verulega hefur nokkuð skýra merkingu og nefndu margir pátttakendur mikilvægi pess að hækka hámarksgreiðslur í fæðingarorlofi til að auka líkur á að karlar, sem tekjuhærri einstaklingar, tækju fæðingarorlof. Sumir nefndu sérstaklega að stefna ætti að pví að fæðingarorlofið yrði pannig að hvort foreldri um sig fengi 5 mánuði og 2 mánuðir væru til skiptanna. Sumir litu á petta sem lið í pví að Brúa umönnunarbilið, sem merkir að ekkert bil sé á milli pess að fæðingarorlofi ljúki og leikskólaganga barns hefst. Priðja efnisatriðið sem felur í sér aðgerðir er Kynjafræðsla á öllum skólastigum sem myndi til dæmis stuðla að pví að bæði kynin líti á pað sem sjálfsagðan hlut að fjölskylduábyrgð karla og kvenna sé jöfn.

\subsection{Kastljósinu beint að tilteknu efnisatriði}

Til að sýna hve áhrifaritið á mynd 1 felur í sér miklar upplýsingar pá verður hér kafað nánar í prjú mikilvæg efnisatriði á áhrifaritinu, en pað eru Staðalmyndir fjari út, Jafnari fjölskylduábyrgð og Aukinn frami kvenna í fyrirtækjum.

Í töflu 1 er dregið fram efnisatriðið Staðalmyndir fjari út. Pegar horft er á örvar að og frá efnisatriðinu á áhrifaritinu á mynd 1, pá sést að pað eru tiltekin atriði sem stuðla að pví að staðalmyndir fjari út (örvar að), en önnur lýsa pví hverju pað myndi skila ef að staðalmyndir fjari út (örvar frá). Í sumum tilvikum eru örvar í báđar áttir inn í petta tiltekna efnisatriði, t.d. jafnari fjölskylduábyrgð og valdefling kvenna. Til að taka nánari dæmi um pátt sem stuðlar að pví að staðalmyndir fjari út, samkvæmt umræðu í rýnihópum, pá var umræðan um fæðingarorlof sú að bætt fæðingarorlof myndi hafa jákvæð áhrif á töku fæðingarorlofs óháð kyni foreldris. Pannig dregur úr peirri staðalmynd að sjálfsagt sé að mæður, frekar en feður, taki lengra fæðingarorlof. Annað atriði sem stuðlar að pví að staðalmyndir fjari út eru einstaklingar sem fyrirmyndir í samfélaginu og pá sér í lagi pegar fjallað er um einstaklinga af öðru kyni en pví sem venjulega tengist tiltekinni starfstétt, s.s. karlar í hjúkrun eða konur í bifvélavirkjun. Kynjafræðsla dregur úr kynjuðum staðalmyndum og áhersla á breyttar staðalmyndir stuðlar að minna kynjuðu starfsvali og kynjaskiptingu starfa.

Dæmi um breytingu sem leiðir af pví að staðalmyndir fjari út er að frami kvenna í fyrirtækjum ætti að aukast, sem síðan stuðlar að jafnari hlutföllum í framkvæmdastjórnum og minni launamuni kynjanna. Einnig má ráðgera að pessi breyting á staðalmyndum myndi leiða til aukinnar valdeflingar kvenna sem stuðla myndi að auknum frama kvenna í fyrirtækjum sem og að jafna hlutföll í framkvæmdastjórnum fyrirtækja. 
Tafla 1. Pættir sem stuðla að pví að staðalmyndir um kyn, karlmennsku og kvenleika fjari út og afleiðingar af peirri breytingu.

\begin{tabular}{|c|c|}
\hline $\begin{array}{l}\text { Pættir sem stuðla að pví } \\
\text { að staðalmyndir fjari út (örvar að) }\end{array}$ & $\begin{array}{l}\text { Afleiðingar af pví } \\
\text { að staðalmyndir fjari út (övar frá) }\end{array}$ \\
\hline Valdefling kvenna, vegna meira gagnsæis í launamálum & $\begin{array}{l}\text { Valdefling kvenna, sem stuðlar að auknum frama kvenna í } \\
\text { fyrirtækjum og jafnari hlutföllum í framkvæmdastjórnum }\end{array}$ \\
\hline Fæðingarorlof verði bætt verulega & Jafnari fjölskylduábyrgð \\
\hline $\begin{array}{l}\text { Jafnari fjölskylduábyrgð, vegna bætts fæðingarorlofs, } \\
\text { jafnari töku fæðingarorlofs og pess að umönnunarbil sé } \\
\text { brúað }\end{array}$ & $\begin{array}{l}\text { Aukinn frami kvenna í fyrirtækjum, sem stuðlar að jafnari } \\
\text { hlutföllum í framkvæmdastjórnum og minni launamunar } \\
\text { kynjanna }\end{array}$ \\
\hline Kynjafræðsla á öll skólastig & Minni kynjaskipting starfa \\
\hline Fjölmiðlar styðji við jafnrétti & $\begin{array}{l}\text { Minna kynjað námsval, sem stuðlar að minni } \\
\text { kynjaskiptingu starfa }\end{array}$ \\
\hline $\begin{array}{l}\text { Fleiri fyrirmyndir karla og kvenna, vegna minna kynjaðs } \\
\text { námsvals og minni kynjaskiptingar starfa }\end{array}$ & \\
\hline
\end{tabular}

Einnig má draga saman á myndrænan hátt pau efnisatriði sem fram koma í heildarritinu, sem og í töflu 1, sjá mynd 2. Par sjást prjár tegundir tengsla, p.e. fjögur atriði hafa áhrif á að staðlmyndir fjara út, tvö eru pess eðlis að áhrifin eru í báðar áttir, en síðan hefur efnisatriðið staðalmyndir fjara út bein áhrif á tvö atriði, með afleiddum áhrifum á jafnari hlutföll í framkævmdastjórnum, minni launamun og minni kynjaskiptingu starfa. Prjár tegundir af römmum í mynd 2 eru samsvarandi og lýst er hér að framan í efnisatriði 1-3.

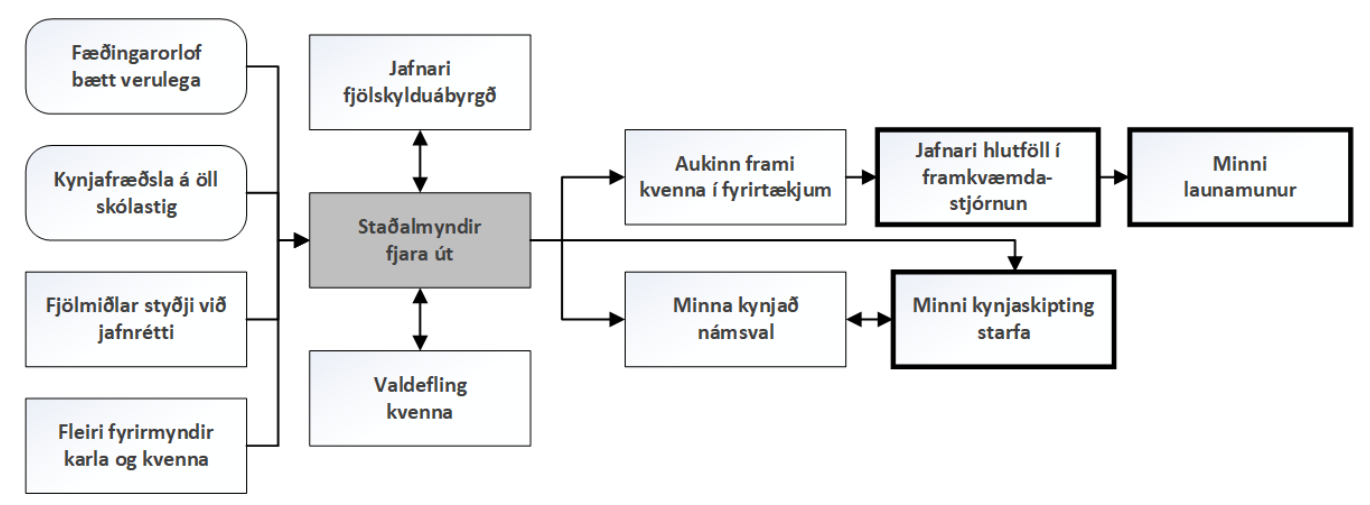

Mynd 2. Áhrif sem stuðla að pví að staðalmyndir fjari út og afleiðingar af peirri breytingu.

Í töflu 2 er dregið fram annað atriði úr áhrifaritinu, en pað er efnisatriðið Jafnari fjölskylduábyrgð. Hér drógu pátttakendur í rýnihópum fram atriði eins og að bætt öldrunarpjónusta jafni fjölskylduábyrgðina, en umræðan var sú að konur öxluðu að öllu jöfnu meiri ábyrgð en karlar á öldruðum foreldrum og jafnvel tengdaforeldrum sem hefði áhrif á stöðu peirra á vinnumarkaði. Pá myndi kynjafræðsla á öllum skólastigum stuðla að jafnari fjölskylduábyrgð, par sem gengið væri út frá pví að foreldrar sinntu pörfum barna til jafns. Jafnari fjölskylduábyrgð gæti síðan stuðlað að minni kynbundnum launamuni við ráðningu, par sem jöfn fjölskylduábyrgð pætti sjálfsögð, sem myndi stuðla að minni launamun kynjanna. 
Tafla 2. Pættir sem stuðla að jafnari fjölskylduábyrgð og afleiðingar af peirri breytingu.

\begin{tabular}{ll}
\hline \multicolumn{1}{c}{\begin{tabular}{c}
\multicolumn{1}{c}{ Pættir sem stuðla að } \\
jafnari fjölskylduábyrgð (örvar að)
\end{tabular}} & \multicolumn{1}{c}{$\begin{array}{c}\text { Afleiðingar af } \\
\text { jafnari fjölskylduábyrgð (örvar frá) }\end{array}$} \\
\hline $\begin{array}{l}\text { Staðalmyndir fjari út } \\
\text { Jafnari taka fæðingarorlofs, vegna pess að fæðingarorlof er } \\
\text { bætt verulega }\end{array}$ & $\begin{array}{l}\text { Staðalmyndir fjari út } \\
\text { Minni kynbundinn launamunur við ráðningu, sem leiðir } \\
\text { til minni launamunar }\end{array}$ \\
$\begin{array}{l}\text { Jafnari taka fæðingarorlofs, vegna pess að umönnunarbiliðð } \\
\text { hefur verið brúað }\end{array}$ & $\begin{array}{l}\text { Fleiri fyrirmyndir karla og kvenna sem leiðir til minna } \\
\text { kynjaðs námsvals og minni kynjaskiptingar starfa }\end{array}$ \\
$\begin{array}{l}\text { Bætt öldrunarpjónusta } \\
\text { Kynjafræðsla á öll skólastig }\end{array}$ & \\
\hline
\end{tabular}

Myndræn framsetning á peim páttum sem stuðla að jafnari fjölskylduábyrgð og afleiðingar af peirri breytingu er sett fram í mynd 3.

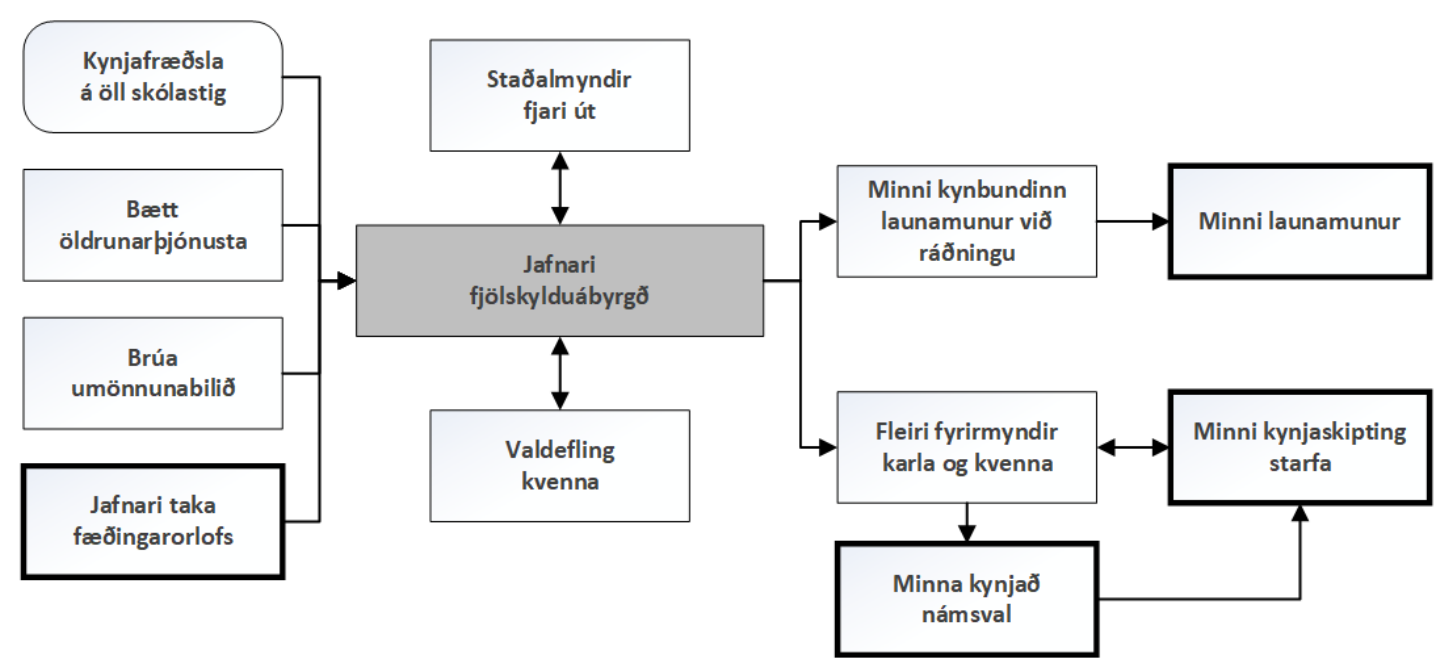

Mynd 3. Áhrif sem stuðla að jafnari fjölskylduábyrgð og afleiðingar af peirri breytingu.

Í töflu 3 er dregið fram priðja dæmið, en pað er efnisatriðið Aukinn frami kvenna í fyrirtækjum. Sem dæmi um pátt sem stuðlar að pessari próun er aukin ábyrgð stjórnenda á pví að jafna stöðu kynjanna, m.a. með frumkvæði í framgangi og ráðningum. Pátttakendur nefndu einnig að lögbinding jafnlaunavottunar væri jákvæður páttur sem stuðla myndi að slíkri próun.

Aukinn frami kvenna gæti síðan stuðlað að jafnari hlutföllum í framkvæmdastjórnum, sem myndi m.a. leiða til pess að draga myndi úr launamuni kynjanna sem og að minna kynjuðu námsvali nemenda. 
Tafla 3. Pættir sem stuðla að auknum frama kvenna í fyrirtækjum og afleiðingar af peirri breytingu.

\begin{tabular}{|c|c|}
\hline $\begin{array}{l}\text { Pættir sem stuðla } \\
\text { að auknum frama kvenna (örvar að) }\end{array}$ & $\begin{array}{c}\text { Afleiðingar af } \\
\text { auknum frama kvenna (övar frá) }\end{array}$ \\
\hline $\begin{array}{l}\text { Aukin ábyrgð stjórnenda á jafnari stöðu kynjanna, t.d. } \\
\text { tilkomið með lögbindingu jafnlaunavottunar }\end{array}$ & $\begin{array}{l}\text { Aukinn frami kvenna í fyrirtækjum myndi stuðla að jafnari } \\
\text { hlutföllum í framkvæmdastjórnum sem myndi stuðla minna } \\
\text { kynjuðu námsvali sem og minni launamuni kynjanna. }\end{array}$ \\
\hline \multicolumn{2}{|l|}{$\begin{array}{l}\text { Valdefling kvenna sem er tilkomin vegna meiri } \\
\text { gagnsæis í launamálum, pví að fæðingarorlof sé } \\
\text { bætt verulega, jafnari fjölskylduábyrgð og pví að } \\
\text { staðalmyndir fjari út }\end{array}$} \\
\hline $\begin{array}{l}\text { Staðalmyndir fjari út vegna valdeflingar kvenna, } \\
\text { gagnsæis í launamálum, jafnari fjölskylduábyrgðar, } \\
\text { kynjafræðslu, aðkomu fjölmiðla og fyrirmynda. }\end{array}$ & \\
\hline
\end{tabular}

Myndræn framsetning á peim páttum sem stuðla að auknum frama kvenna í fyrirtækjum og afleiðingar af peirri breytingu er sett fram í mynd 4. Einnig hefði mátt bæta inn á myndina ástæðum pess að staðalmyndir fjari út, eins og gert er í töflu 3, en ekki pótti ástæða til að flækja myndina um of með pví að bæta inn slíkum áhrifapáttum par sem peim eru gerð nánari skil í töflunni.

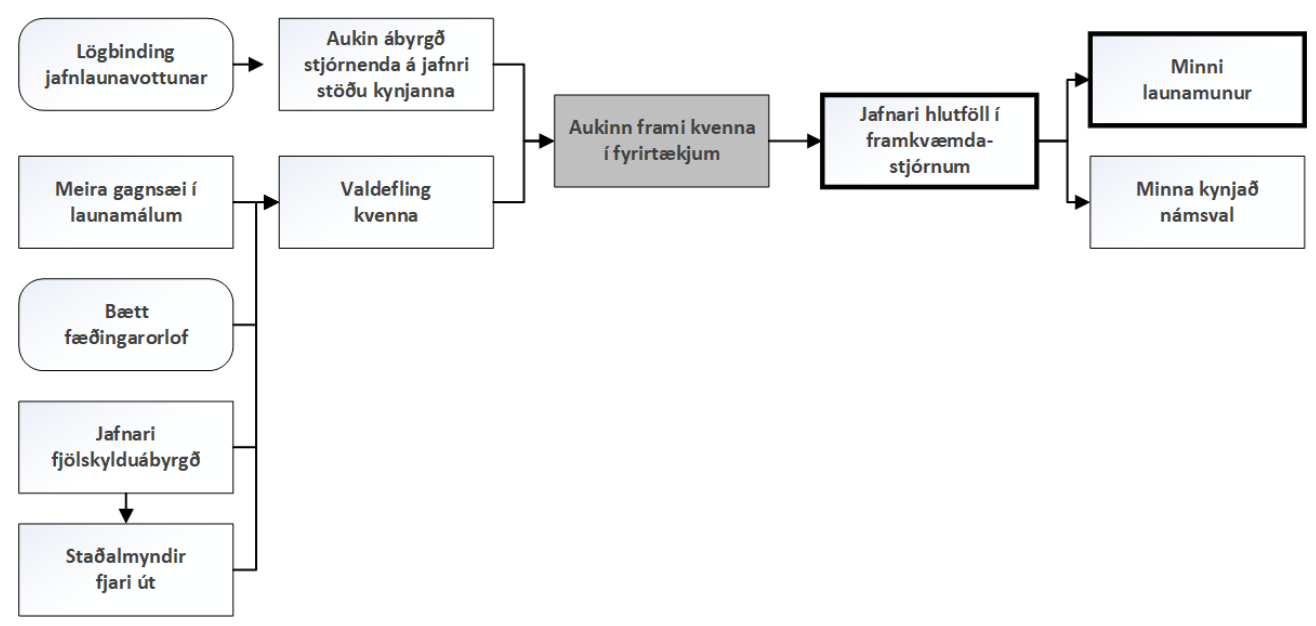

Mynd 4. Áhrif sem stuðla að auknum fram kvenna í fyrirtækjum og afleiðingar af peirri breytingu.

\subsection{Margt má lesa úr áhrifaritinu}

Eins og sjá má á myndum 1-4 má lesa ýmis keðjuáhrif úr áhrifaritinu og peim skýringarmyndum sem settar hafa verið fram. Til að mynda: Hvernig hefur bætt fæðingarorlof áhrif á kynjaskiptingu starfa? Af myndinni sést að bætt fæðingarorlof hefur áhrif á jafnari fjölskylduábyrgð, bæði í gegnum jafnari töku fæðingarorlofs og í gegnum brúun umönnunarbilsins. Jafnari fjölskylduábyrgð hefur áhrif á bæði staðalmyndir og fyrirmyndir sem hvoru tveggja hefur áhrif á kynjaskiptingu starfa. Bætt fæðingarorlof hefur auk pess áhrif á valdeflingu kvenna sem hefur áhrif á staðalmyndir. Áhrifaritið sýnir pannig að bætt fæðingarorlof myndi hafa áhrif á kynjaskiptingu starfa á margan hátt og pví ekki óvænt að pátttakendur í rýnifundunum teldu petta mikilvægt atriði. Áhrifaritið sýnir líka hvernig bætt fæðingarorlof myndi hafa áhrif á launamun á ýmsan hátt, að mati pátttakenda.

Áhrifaritið getur veitt fyrstu svör við ýmsum spurningum. Tökum sem dæmi spurningarnar „Hvað stendur upp á stjórnvöld til að jafna stöðu kynjanna og hvað stendur upp á stjórnendur fyrirtækja?“. Pó nokkur atriði á áhrifaritinu snúa að stjórnvöldum, t.d. 
Lögbinding jafnlaunavottunar, Fæðingarorlof verði bætt verulega, Brúa umönnunarbilið og Bætt öldrunarpjónusta. Prjú atriði snúa sérstaklega að stjórnendum í fyrirtækjum: Aukin ábyrgð stjórnenda á jafnari stöðu kynjanna, Endurmat launakerfa innan fyrirtækja og Meira gagnsæi i launamálum. Áhrifaritið sýnir mjög skýrt að fjölmargir munu hafa áhrif á próunina, par á meðal skólastjórar og kennarar, starfsmenn fjölmiðla og nýbakaðir foreldrar.

Áhrifaritið segir ekki eitt og sér hvað sé mikilvægast til að staða kynjanna í íslensku atvinnulífi jafnist sem hraðast, en hver og einn getur notað pað til að hjálpa sér að meta pað. Раð er t.d. ljóst að fjölskylduábyrgð og staðalmyndir, sem eru atriði sem tengjast sterkt, hafa afar mikil áhrif. Allt sem stuðlar að jafnari fjölskylduábyrgð og að pví að staðalmyndir karla og kvenna verði líkari, mun hafa mikil áhrif. Menntakerfið hlýtur að leika hér lykilhlutverk á svo ótal marga vegu og pað væri efni í stóra rannsókn. Sú einstaka aðgerð sem má færa rök fyrir pví að hefði fljótt mikil áhrif væri að lengja pann tíma fæðingarorlofs sem feður fá.

\section{Umræður}

Rannsóknarverkefnið um stöðu kynjanna í íslensku atvinnulífi hófst í byrjun árs 2017 og er hugsað sem nokkurra ára verkefni. Fyrsti áfanginn fólst í pví að draga upp ígrundaða heildarmynd af viðfangsefninu og er hún kynnt í pessari grein. Pessi heildarmynd stendur ein og sér og veitir umtalsverðar upplýsingar. Hún getur verið útgangspunktur í umræðu um viðfangsefnið. Hana má líta á sem leið til að skilgreina rannsóknir sem hafa pað að markmiði að kafa ofan í tiltekna pætti viðfangsefnisins og er í pessum kafla rætt um nokkra slíka möguleika.

Rannsóknarspurningin sem fengist var við er eftirfarandi: Hvaða pættir geta stuðlað að jafnri stöðu kynjanna i íslensku atvinnulífi? Margir pættir (pemu) komu fram í rýnihópunum, en prír voru ræddir sérstaklega: Staðalmyndir fjari út, Jafnari fjölskylduábyrgð og Aukinn frami kvenna í fyrirtækjum.

Staðalmyndir fjari út: Fram kom í rýnihópunum að bætt fæðingarorlof myndi hafa jákvæð áhrif á töku fæðingarorlofs óháð kyni foreldris. Pessi niðurstaða dregur úr peirri staðalmynd að sjálfsagt sé að mæður, frekar en feður, taki lengra fæðingarorlof. Annað atriði sem kom fram í hópunum sem stuðlar að pví að staðalmyndir fjari út eru einstaklingar sem fyrirmyndir í samfélaginu og pá sér í lagi pegar fjallað er um einstaklinga af öðru kyni en pví sem venjulega tengist tiltekinni starfstétt, s.s. karlar í hjúkrun eða konur í bifvélavirkjun. Áherslur á breyttar staðalmyndir byggja til að mynda á minna kynjuðu starfsvali og kynjaskiptingu starfa og er í samræmi við kenningar Eagly og Karau (2002) um að ósamræmi kynhlutverka geti verið hindrun í vegi pess að konur komist í áhrifastöður.

Dæmi um breytingar sem leiða af pví að staðalmyndir fjari út er að fleiri fyrirmyndir að konum í leiðtogastörfum verða til og frami kvenna í fyrirtækjum ætti að aukast, sem síðan stuðlar að jafnari hlutföllum í framkvæmdastjórnum og minni launamuni kynjanna sem er í samræmi við niðurstöður Koenig o.fl. (2011) og Kray og Thompson (2004). Einnig má ætla að pessi breyting á staðalmyndum myndi leiða til aukinnar valdeflingar kvenna sem stuðla myndi að auknum frama kvenna í fyrirtækjum sem og jafna hlutföll í framkvæmdastjórnum fyrirtækja. Áherslan á staðalmyndir bendir til að pátttakendur hafni pví að eðlismunur sé á körlum og konum (Hakim, 2002), sem styður niðurstöður Unnar Dóru Einarsdóttur, Erlu S. Kristjánsdóttur og Póru H. Christiansen (2017) sem sýna að kvenmillistjórnendur upplifa sem hindrun að pær falli ekki að karllægri staðalmynd yfirstjórnandans og niðurstöður Guðbjargar Lindu Rafnsdóttur og Margrétar Porvaldsdóttur (2012) sem sýna að bæði konur og karlar í yfirstjórnum íslenskra fyrirtækja telja íhaldssamar staðalmyndir hindra framgang kvenna í stjórnunarstöður á íslenskum vinnumarkaði.

Jafnari fjölskylduábyrgð: Fram kom í rýnihópunum að bætt öldrunarbjónusta muni jafna fjölskylduábyrgðina vegna pess að konur axla að öllu jöfnu meiri ábyrgð á öldruðum foreldrum og jafnvel tengdaforeldrum en karlar sem hefði áhrif á stöðu peirra á vinnumarkaði. En fyrri rannsóknir (t.d. Blair-Loy, 2001) hafa sýnt fram á að enn sé konum ætlað að 
bera meginábyrgðina á umönnun barna og heimilis en körlum að vera fyrirvinnur. Konur í forstjórastöðum upplifa meiri ábyrgð á umönnun fjölskyldunnar en karlar í sömu stöðum og vinna karlarnir lengri vinnudag utan heimilis (Júlíusdóttir, Rafnsdóttir og Einarsdóttir, 2018). Pessar niðurstöður skýra ólíkan framgang karla og kvenna út frá pví að samfélagsleg viðhorf til karla og kvenna eru ólík (Blair-Loy, 2001; Eagly og Karau, 2002; Koenig o.fl., 2011). Enn fremur kom fram í rýnihópnum að jafnari fjölskylduábyrgð gæti síðan stuðlað að minni kynbundnum launamuni við ráðningu, par sem jöfn fjölskylduábyrgð pætti sjálfsögð, sem myndi stuðla að minni launamun kynjanna. Pessi ójafna fjölskylduábyrgð hefur mikil áhrif á stöðu kvenna í atvinnulífinu og á meðan fjölskylduábyrgð kynjanna er ójöfn pá verður staða kynjanna í atvinnulífinu ójöfn en pörf er á frekari rannsóknum á pessu sviði.

Aukinn frami kvenna i fyrirtækjum: Priðji pátturinn sem kom skýrt fram í rýnihópunum var aukinn frami kvenna í fyrirtækjum. Enn fremur kom fram að páttur sem stuðlar að pessari próun er aukin ábyrgð stjórnenda á pví að jafna stöðu kynjanna. Pessi niðurstaða rímar við rannsókn Arneyjar Einarsdóttur, Katrínar Ólafsdóttur og Laura Nesaule (2018) sem sýndi að tilvist jafnréttisáætlunar fyrirtækis hafði ekki áhrif á upplifun starfsfólks af kynjajafnrétti en pað sem hafði jákvæð áhrif á upplifun af jafnrétti var aukið proskastig jafnréttis skipulagsheilda sem lýsir sér í frumkvæði skipulagsheildarinnar í jafnréttismálum, svo sem greiningum eða jákvæðri mismunun. Arney o. fl. benda á pörfina fyrir frumkvæði fyrirtækja í jafnréttismálum og að pau auki gagnsæi t.d. í frammistöðumati, launasetningu og ákvarðanatöku. Pátttakendur nefndu sem dæmi að lögbinding jafnlaunavottunar væri jákvæður páttur sem stuðla mundi að slíkri próun. Aukinn frami kvenna gæti síðan stuðlað að jafnari hlutföllum í framkvæmdastjórnum, sem myndi m.a. leiða til pess að draga myndi úr launamuni kynjanna sem og að minna kynjuðu námsvali nemenda.

Starfsval er að mörgu leyti kynbundið og pað parf alla vega tvennt til að ná fram verulegri breytingu á pví. I fyrsta lagi eru lægri laun í mörgum hefðbundnum kvennastörfum en í karlastörfum og fælir pað karla frá peim. Sem dæmi má nefna pá er, samkvæmt gildandi kjarasamningum, háskólamenntaður starfsmaður með B.ed. próf í leikskólakennarafræðum með kr. 404.080 í laun (Kennarasamband Íslands, 2018) á meðan meðalgrunnlaun tölvunarfræðinga með háskólapróf, óháð kyni, eru kr. 769.018 en karla í pessari grein kr. 782.866. Hér er ekki um kjarasamninga að ræða, en niðurstöður kjarakönnunar (VR, e.d.a). Petta eru pví einkum afleiðing kjarasamninga og einstaklingsbundinna samninga og líklega er erfitt að stýra próun pess nema að pví leyti sem ríki, sveitarfélög og vinnuveitendur geta tekið mið af pví í eigin kjarasamningum. İ öðru lagi ráða viðhorf pví að börn og ungt fólk íhugar ekki mörg störf sem "frátekin eru fyrir hitt kynið”. Um pessar mundir eru margir að vinna að pví að breyta pessu, m.a. átakið „öll störf eru kvennastörf” (sjá www. kvennastarf.is).

\section{Lokaorð}

Í pessari grein er gerð grein fyrir niðurstöðum rannsóknarverkefnis um kynjamun í íslensku atvinnulífi sem hefur pað markmið að ná djúpum skilningi á pví hvað mögulegt er að gera til að jafna stöðu kynjanna. Í rannsókninni er dregið fram í hverju ójöfn staða kynjanna í atvinnulífinu felst og pá sérstaklega hvað geti orðið til pess að jafna pá stöðu. Markmiðið var að draga fram meginpætti málsins og samhengi peirra sem var gert með áhrifariti. Áhrifaritið er ekki endanlegt en pað endurspeglar sýn fjölmargra einstaklinga, sérfræðinga og hagsmunaaðila, á samfélagið og samspil pess við vinnumarkaðinn. Áhrifaritið nær utan um meginatriði málsins og byggir pannig traustan grunn fyrir frekari rannsóknir. Í næstu áföngum rannsóknarverkefnisins er ætlunin að kafa dýpra í einstaka pætti viðfangsefnisins og pannig nýtist pessi áfangi við að skilgreina pær rannsóknir á markvissan hátt.

Nokkur rannsóknarverkefni, sem dýpkað geta niðurstöður pessarar rannsóknar, blasa við í framhaldi af pessum fyrsta áfanga eins og rakið var í greininni. Sem dæmi um áhuga- 
verð rannsóknarverkefni má nefna eftirfarandi. Í fyrsta lagi er ljóst að ójöfn fjölskylduábyrgð kynjanna hefur mikil áhrif á stöðu kynjanna í atvinnulífinu og pví mikilvægt að greina pað betur, bæði hvað parf að breytast og hvaða aðgerðir geta stuðlað að breyttri stöðu. I öðru lagi er mikilvægt að kafa dýpra í ástæður pess að frami kvenna er minni en karla í fyrirtækjum. Í priðja lagi má nefna kynbundið náms- og starfsval og í fjórða lagi hvað grunnskólinn gæti gert betur til að stuðla að jafnari stöðu kynjanna í atvinnulífinu og pjóðfélaginu í heild. Rannsóknartækifærin eru óendanlega mörg.

Niðurstöður rannsóknarinnar geta nýst við frekari rannsóknir á viðfangsefninu. Stjórnvöld og fleiri gætu einnig haft gagn af pessu, m.a. við stefnumörkun í jafnréttismálum eða við einstaka ákvarðanir. Einnig gætu niðurstöður gagnast fyrirtækjum sem vilja stuðla að auknu jafnrétti kynja í atvinnulífinu, m.a. með pví að skapa umræður innan peirra um aðgerðir sem að stjórnendur fyrirtækjanna geta gripið til eða stutt við.

Rýnihópafundirnir og niðurstöður peirra eru góður grunnur undir framsetningu heildarmyndar, sem bæði segir margt eins og hún er og nýtist einnig vel til pess að afmarka frekari rannsóknir par sem kafað verður dýpra ofan í einstaka pemu. Í engum tilvikum er reynt að sanna að um orsakasamband sé að ræða, heldur á áhrifaritið að endurspegla sýn pátttakendanna á rýnifundunum á hvaða orsakasambönd eru sterk.

Ljóst er að margt parf að koma til svo að staða kynjanna í atvinnulífinu verði jöfn. Meðal annars parf að verða hugarfarsbreyting í pjóðfélaginu, en slíku er ekki hægt að breyta beint, en margt er hægt að gera til að hafa áhrif á hugarfar. Fjölmiðlar, einstaka stjórnendur og fjölmargir aðrir hafa sitt hlutverk í pessari vinnu, en stjórnvöld geta pó leikið lykilhlutverk. Lög um jafnlaunavottun er dæmi um slíkt og einnig er augljóst að breytingar á fæðingarorlofi sem leiddu til pess að feður myndu verja meiri tíma með ungabörnum gætu haft mikil áhrif. En pað er margt fleira sem stjórnvöld geta gert, til að mynda að efla kynjafræðslu og tengd viðfangsefni í skólakerfinu. Með frekari rannsóknum er hægt að auðvelda stjórnvöldum að taka ákvarðanir sem hafa mikil áhrif á framvindu mála. Páttur fyrirtækja og stjórnenda er einnig stór og sýnir áhrifaritið að atvinnulífið parf að taka höndum saman við stjórnvöld og einstaklinga til að vinna að pví að jafna stöðu kvenna og karla.

\section{Heimildir}

Arney Einarsdóttir, Katrín Ólafsdóttir og Laura Nesaule (2018). The relationship between gender equality activity in organizations and employee perceptions of equality. Tímarit um viðskipti og efnahagsmál 15(1), 37-53.

Aðalsteinn Leifsson og Aldís G. Sigurðardóttir. (2010). Gender in individual salary negotiations: Learning to counter-offer. Rannsóknir í félagsvísindum XI. Reykjavík: Félagsvísindastofnun Háskóla Íslands

Alexander, G.C. (2002). Interactive management: An emancipatory methodolog. Systemic Practice and Action Research, 15(2), 111-122. https://doi.org/10.1023/A:1015288407759

Axelsdóttir, L. og Einarsdóttir, P. (2017). The realization of gender quotas in post-collapse Iceland. NORANordic Journal of Feminist and Gender Research, 25(1), 48-61.

Axelsdóttir, L., og Halrynjo, S. (2018). Gender Balance in Executive Management: Top-Managers' Understanding of Barriers and Solutions from the Demand-Supply Perspective. Social Politics: International Studies in Gender, State \& Society, 25(2), 287-314.

Blair-Loy, M. (2001). Cultural Constructions of Family Schemas The Case of Women Finance Executives. Gender E Society, 15(5), 687-709.

Blau, F. D. og Kahn, L. M. (2007). The gender paygap: Have women gone as far as they can? Academy of Management Perspectives, 21(1), 7-23.

Broome, B. J., DeTurk, S., Kristjansdottir, E. S., Kanata, T. og Ganesan, P. (2002). Giving voice to diversity: An interactive approach to conflict management and decision-making in culturally diverse work environments. Journal of Business and Management 8(3), 239-264.

Bryman, A. og Bell, E. (2007). Business research methods (2. útg.). Oxford: Oxford University Press.

Burnett, J. (2009). Doing your Social Science Dissertation. London: Sage Publication, Inc.

Creswell, J. W. (2007). Qualitative inquiry and research design: Choosing among five approaches (2. útg.). Thousand Oaks: Sage Publications, Inc.

Delbeq, A. L., Van De Ven, A. H. og Gustafson, D. H. (1975). Group techniques for program planning: A guide to nominal group and DELPHI processes. Glenview, IL: Scott, Foresman. 
Eagly, A. H., og Karau, S. J. (2002). Role congruity theory of prejudice toward female leaders. Psychological review, 109(3), 573.

Eden, C. (1989). Using cognitive mapping for strategic options development and analysis (SODA), í Rosenhead (1989) Rational analysis for a problematic world: Problem structuring methods for complexity, uncertainty and conflict. Chichester: John Wiley \& sons.

Einar Mar Pórðarson, Heiður Hrund Jónsdóttir, Fanney Pórsdóttir, Ásdís A. Arnalds og Friðrik H. Jónsson. (2008). Kynbundinn launamunur á íslenskum vinnumarkaði. Félagsvísindastofnun Háskóla Íslands.

Elborgh-Woytek, K., Newiak, M., Kochhar, K., Fabrizio, S., Kpodar, K., Wingender, P., Clements, B. og Schwartz, G. (2013). Women, work and the economy: macroeconomic gains from gender equity. IMF staff discussion note, 13/10. International Monetary Fund.

Farsari, I., Butler, R. W. og Szivas, E. (2011). Complexity in tourism policies: A Cognitive Mapping Approach. Annals of Tourism Research, 38(3), 1110-1134.

Fjóla Pórdís Jónsdóttir og Ingi Rúnar Eðvarðsson. (2013). Kynbundnir áhrifapættir á starfsval sál- og tæknifræðinga. Íslenska pjóðfélagið 4, 65-82.

Guðbjörg Linda Rafnsdóttir og Margrét Porvaldsdóttir. (2012). Kynjakvótar og mögulegar hindranir á leið kvenna til æðstu stjórnunar. Íslenska pjóðfélagið, 3, 57-76.

Guðbjörg Vilhjálmsdóttir. (2004). Ólík hugsun um störf eftir kynferði. Rannsóknir í félagsvísindum V. Reykjavík: Félagsvísindastofnun Háskóla Íslands.

Gyða Margrét Pétursdóttir. (2010). Homo economicus meets Homo holismus. Men and women discuss their salaries within different frames of reference. Rannsóknir i félagsvísindum XI. Reykjavík: Félagsvísindastofnun Háskóla Íslands.

Hagstofa Íslands (e.d.). Talnaefni - Háskólastig. Sótt af https://hagstofa.is/talnaefni/samfelag/menntun/haskolastig

Hagstofa Íslands. (2018). Launamunur kynjanna dregst saman. Sótt af https://hagstofa.is/utgafur/frettasafn/launog-tekjur/rannsokn-a-launamun-kynjanna-2008-2016/

Hagstofa Íslands. (2019a). Konur og karlar á Íslandi 2019. Sótt af http://hagstofan.s3.amazonaws.com/media/ public/2019/f691d1ec-d651-4380-a68d-df7893e83e42.pdf

Hagstofa Íslands. (2019b). Konur priðjungur stjórnarmanna stórra fyrirtækja. Sótt af https://hagstofa.is/utgafur/ frettasafn/fyrirtaeki/stjornir-og-framkvaemdastjorar-fyrirtaekja-2018/

Hakim, C. (2002). Lifestyle preferences as determinants of women's differentiated labor market careers. Work and occupations, 29(4), 428-459.

Hakim, C. (2006). Women, careers, and work-life preferences. British Journal of Guidance E Counselling, 34(3), 279-294.

Háskóli Íslands (2018). Lykiltölur 2017. Sótt 11. september 2018 á https://issuu.com/haskoliislands-universityoficeland/docs/lykilt_lur_slens2018.

Herrera, H. J., McCardle-Keurentjes, M. H. F. og Videira, N. (2016). Evaluating Facilitated Modelling Processes and Outcomes: An Experiment Comparing a Single and a Multimethod Approach in Group Model Building. Group Decision and Negotiation, 25,1277-1318.

Júlíusdóttir, Ó., Rafnsdóttir, G. L., \& Einarsdóttir, P. (2018). Top managers and the gendered interplay of organizations and family life: the case of Iceland. Gender in Management: An International Journal, 33(8), 602-622.

Kaplan, R. S. og Norton, D. P. (2001). The Strategy Focused Organization: How balanced scorecard companies thrive in the new business environment. Boston: Harvard Business School Press.

Katrín Ólafsdóttir og Steinunn Rögnvaldsdóttir. (2015). Staða kvenna og karla á íslenskum vinnumarkaði. Velferðarráðuneytið.

Kennarasamband Íslands (2018). Leikskólakennarar, launatafla B, Gildir frá 1. júní 2018 til 30. júní 2019. Sótt af https://ki.is/kjaramal/kaup-kjor/kjarasamningar/felag-leikskolakennara\#leiksk\%C3\%B3lakennarar-launatafla-b-\%C3\%AD-gildi-1-j\%C3\%BAn\%C3\%AD-2018-til-30-j\%C3\%BAn\%C3\%AD-2019.

Koenig, A. M., Eagly, A. H., Mitchell, A. A., og Ristikari, T. (2011). Are leader stereotypes masculine? A metaanalysis of three research paradigms. Psychological bulletin, 137(4), 616.

Kray, L. J., og Thompson, L. (2004). Gender stereotypes and negotiation performance: An examination of theory and research. Research in organizational behavior, 26, 103-182.

Kvale, S., \& Brinkmann, S. (2009). Interviews: Learning the Craft of Qualitative Research Interviewing (2 ed.). Thousand Oaks: SAGE Publications, Inc.

Lög um breytingu á lögum nr. 10/2008 um jafna stöðu og jafnan rétt kvenna og karla með síðari breytingum (jafnlaunavottun) nr. 56/2017. Sótt af https://www.althingi.is/altext/146/s/1054.html

Læknafélag Íslands (e.d.). Sótt af http://www.lis.is/UtgefidEfni/Hagdeild/nanar/4942/samantekt-a-vinnuaflilaekna.

McRae, S. (2003). Constraints and choices in mothers' employment careers: a consideration of Hakim's preference theory. The British journal of sociology, 54(3), 317-338.

Margrét Sæmundsdóttir. (2009). Konur og stjórnarhættir fyrirtækja á Íslandi. Bifröst Journal of Social Science, 3 , 5-26. 
Nasdaq Global newswire (2017). Kauphöllin hringir opnunarbjöllu fyrir jafnrétti kynjanna í tilefni að Alpjóðadegi kvenna 8. Mars. Sótt af https://globenewswire.com/news-release/2017/03/06/931698/0/is/Kauphöllin-hringir-opnunarbjöllu-fyrir-jafnrétti-kynjanna-í-tilefni-að-Alpjóðadegi-kvenna-8-mars.html.

Ólafsdóttir, K. (2018). Iceland is the best, but still not equal. Sökelys på arbeidslivet, 35(01-02), 111-126.

Rosenhead, J. (ritstjóri) (1989). Rational analysis for a problematic world: Problem structuring methods for complexity, uncertainty and conflict. Chichester: John Wiley \& sons.

Schein, V. E. (1973). The relationship between sex role stereotypes and requisite management characteristics. Journal of Applied Psychology, 57(2), 95-100.

Schein, V. E. (2007). Women in management: reflections and projections. Women in Management Review, 22(1), 6-18.

Sif Einarsdóttir. (2005). Kynjamunur í starfsáhuga-raunverulegur eða skekkja í áhugakönnunum? Áhrif kynbundinna staðalmynda á starfsáhuga karla og kvenna. Í Arna Jónsdóttir, Steinunn Helga Lárusdóttir og Pórdís Pórðardóttir (ritstj.). Kynjamyndir í skólastarfi (103-123). Reykjavík: Rannsóknastofnun Kennaraháskóla Íslands:

Sigurður Snævarr. (2015). Launamunur karla og kvenna. Velferðarráðuneytið.

Slotsky, J. (2006). Gender and its relevance to Macroeconomic policy: A survey. IMF Working Paper WP/06/233.

Snjólfur Ólafsson (2005). Stefnumiðað árangursmat sem liður í framkvæmd stefnu. Tímarit um viðskipti og efnahagsmál 3(1), 47-72.

Unnur Dóra Einarsdóttir, Erla S. Kristjánsdóttir og Póra H. Christiansen. (2017). „....hvað segið pið strákar?“ Upplifun kvenmillistjórnenda af stöðu sinni, möguleikum og hindrunum í starfi. Tímarit um viðskipti og efnahagsmál, 14(1), 1-24.

Valgerður Jóhannsdóttir og Porgerður Einarsdóttir. (2015). „Gender bias in the media: the case of Iceland”. Stjórnmál \& stjórnsýsla 11(2), 207-230.

Velferðarráðuneytið (2018). Skýrsla félags- og jafnréttismálaráðherra um stöðu og próun jafnréttismála 2015-2017. Velferðarráðuneytið.

VR (e.d.a) Starfsheiti og atvinnugrein, starfsheiti: Tölvunarfræðingar með háskólapróf. Sótt af https://www.vr.is/ kannanir/launakonnun-2016/reiknadu-launin/.

VR (e.d.b). Launamunur kynjanna. Sótt af https://www.vr.is/kannanir/launakonnun-2018/launamunurkynjanna/

World Economic Forum (2018). The Global Gender Gap Report 2018. Sótt af http://www3.weforum.org/docs/ WEF_GGGR_2018.pdf

Porlákur Karlsson, Margrét Jónsdóttir og Hólmfríður Vilhjálmsdóttir. (2007). Kvennanafn lækkar launin: Tilraun á mögulegum skýringum á óútskýrðum launamuni karla og kvenna. Reykjavík: Háskólinn í Reykjavík.

Puríður Sigurjónsdóttir og Sif Einarsdóttir (2011). Kyngervi raunvísinda: Námsval og aðstæður kvenna í hefðbundnum karlagreinum við Háskóla Íslands. Tímarit um menntamál, 8, 80-101. 